\title{
BIOCHEMICAL AND HEMATOLOGICAL VALUES OF THE BLOOD IN RAMS DURING REARING
}

\author{
P. JELÍNEK, J. ILLEK ${ }^{1}$, IVANA HELANOVÁ and Z. FRAIS ${ }^{2}$
}

Department of Cattle, Horse and Sheep Breeding, University of Agriculture, 66265 Brno; ${ }^{22}$ Department of Reproduction, Zoohygiene and Technology of Animal Products, University of Agriculture, Brno; 'Department of Diagnosis, Therapy and Prevention of Animals Diseases, University of Veterinary Science, 61242 Brno

Received September 12, 1983

\begin{abstract}
Jelínek P., J. Illek, Ivana Helanová, Z. Frais: Biochemical and Hematological Values in the Blood of Rams during Rearing. Acta vet. Brno, 53, 1984: 143-150.

The dynamics of some hematological and biochemical indices was studied in 45 rams reared in a central stock rearing house in the breeding season of 1982/1983. The results showed that the observed biochemical and hematological values correspond with the physiological standard. With advancing age a decrease was observed of the total count of erythrocytes, hemoglobin, hematocrit, inorganic phosphorus and glucose. The nutritional level affected the content of urea and phosphorus in the blood plasma. A negative, highly significant correlation was proved between the age and the glucose level, and a positive, highly significant relationship between the total protein content and amount of wool in the grease and technically clean wool.

The data obtained in this study may be employed for evaluation of the health status and nutrition of rams during rearing. The data may also serve as reference values for Merino ram-lambs in the respective age categories.
\end{abstract}

Rams, blood picture, nutrition, age, blood plasma, biochemistry.

The presumption for a full development of genetic potential of all the productive characters of sheep are suitable environmental conditions during rearing. In order to evaluate their effect upon the developing organisms, however, it is necessary to know as many indices as possible, as they reflect these effects and, signalize the level of nutrient supply, mineral substances, vitamins; at the same time, they manifest the functional condition of the animal. From this aspect most important is knowledge about the basic hematological and biochemical blood indices which holds good especially in the young, developing animals. The importance of these laboratory analyses increases with the loading of the organism, may it be the effect of inconventional technology, degree of exploitation, method of nutrition, use of new genotypes, or when evaluating various experimental measures.

Many studies have been written dealing with hematological values and metabolic profile of sheep blood (Soliman et al. 1975; Thomas and Axford 1968; Holub et al. 1969; Sova and Medŕický 1972; Hofírek 1978; Jelínek et al. 1982, 1983; Vrzgula et al. 1965, 1973, 1982; Underwood 1971; Hennig 1972; Bolšedanov 1973; Ried et al. 1974; Vrzgula and Skalka 1977; Jagoš et. al. 1980a). Only few studies were aimed at determination of the basic hematological and biochemical data with respect to age, sex, season, breed, etc.

Therefore in the present study the basic hematological parameters and indices of the metabolic profile of blood plasma in Merino rams were studied. Suitability of these indices for evaluation of their nutritional status and metabolic disorders was verified as well. 


\section{Materials and Methods}

Mean hematological and biochemical values were estimated in 45 randomly selected, clinically healthy rams of Merino breed reared in the stock rearing houses of the Regional Breeding Enterprise in Ceské Budějovice - Závraty. The animals were deep-litter housed in groups of 10 animals and fed ad libitum with a complete granulated mixture which was supplemented with hay and grazing after the end of the testing period. During rearing the ram-lambs were wormed three times (May 19, 1982, October 13, 1982 and January 19, 1983).

Blood was examined in 4 time periods with regard to selective interventions, i. e. prior to the testing period on March 29, 1982 (average age 90 days and live weight $24.0 \mathrm{~kg}$ ), after the end of the testing period on June 4, 1982 (average live weight $42.3 \mathrm{~kg}$ ), on November 2, 1982 (average live weight $58.8 \mathrm{~kg}$ ), the last sampling was done on January 18, 1983 (average live weight $74.8 \mathrm{~kg}$ ).

Blood was taken from the $\mathrm{v}$. jugularis into heparinized test tubes at the same time of the day and from the same animals, the number of which decreased in the course of rearing due to gradual selection. Blood plasma for the estimation of biochemical values was obtained up to 30 minutes after blood collection. From these blood samples the following hematological values were estimated using the classical method: erythrocytes, hemoglobin, hematocrit value, mean corpuscular hemoglobin concentration (MCHC), mean corpuscular hemoglobin $(\mathrm{MCH})$, mean corpuscular value (MCV), leukocytes and their differential count. The total protein level was estimated using the biuret reaction on an Eppendorf photometric line, the content of sodium potassium, calcium, magnesium, copper, and zinc using the AAS method on the Atomspek apparatus by Hilger. Inorganic phosphorus, glucose and urea in the plasma were determined photometrically using the Lachema Bio-Test sets.

Wool production and live weight of the selected animals were investigated for calculations of some correlation relationships among selected indices of the internal environment.

\section{Results}

Total mathematical-statistical characteristics of the hematological and biochemical values studied are give in Tables $1-4$. The significance of differences tested using variance analyses is given in Tab. 5 .

Table 1

Total mathematical-statistical characteristics of hematological and biochemical indices at the age of 90 days (before the beginning of the testing period).

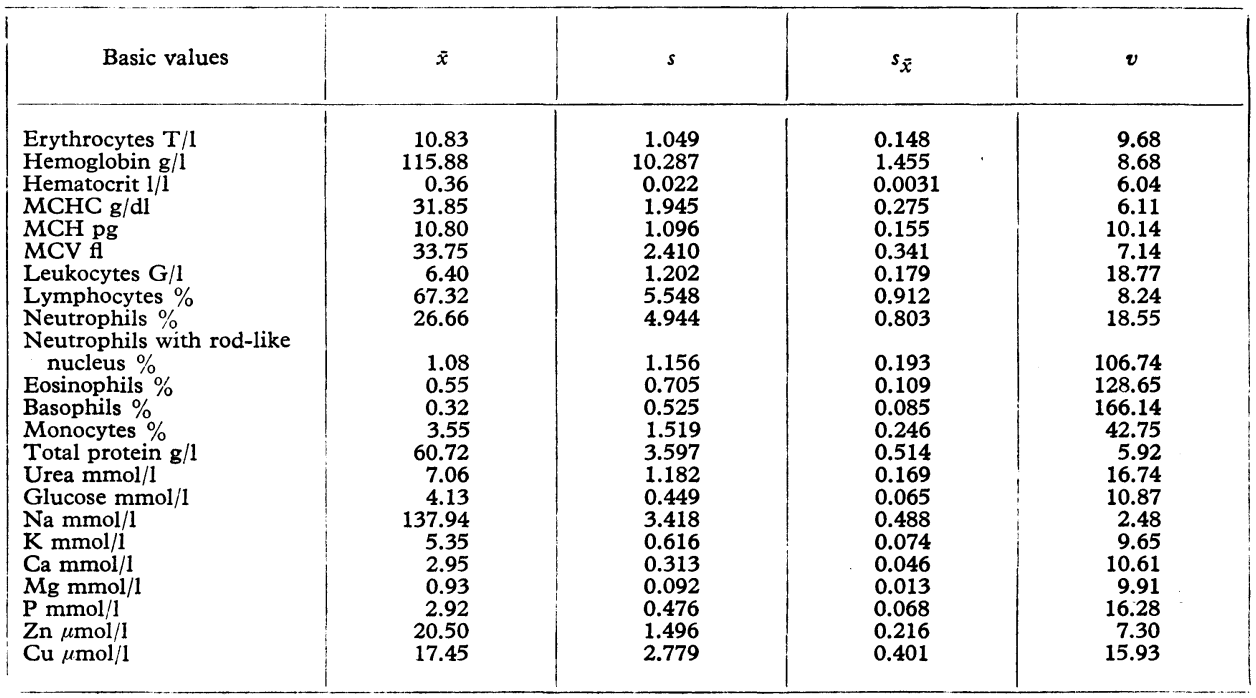




\section{Discussion}

A decreasing trend was observed in the total number of erythrocytes, hemoglobin and hematocrit values during the rearing of ram-lambs, and between the individual time intervals highly significant differences were statistically proved in the majority of cases. The average number of erythrocytes ranged between

Table 2

Total mathematical-statistical characteristics of hematological and biochemical indices at the age of 150 days (after the testing period)

\begin{tabular}{|c|c|c|c|c|}
\hline Basic values & $\bar{x}$ & $s$ & $s_{\bar{x}}$ & $v$ \\
\hline $\begin{array}{l}\text { Erythrocytes T/1 } \\
\text { Hemoglobin g/l } \\
\text { Hematocrit } 1 / 1 \\
\text { MCHC g/dl } \\
\text { MCH pg } \\
\text { MCV fl } \\
\text { Leukocytes G/1 } \\
\text { Lymphocytes \% } \\
\text { Neutrophils \% } \\
\text { Neutrophils with rod-like } \\
\text { nucleus \% } \\
\text { Eosinophils \% } \\
\text { Basophils \% } \\
\text { Monocytes \% } \\
\text { Total protein g/dl } \\
\text { Urea mmol/1 } \\
\text { Glucose mmol/1 } \\
\text { Na mmol/1 } \\
\text { K mmol/1 } \\
\text { Ca mmol/1 } \\
\mathrm{Mg} \mathrm{mmol} / 1 \\
\mathrm{P} \text { mmol/1 } \\
\mathrm{Zn} \mu \mathrm{mol} / 1 \\
\mathrm{Cu} \mu \mathrm{mol} / 1\end{array}$ & $\begin{array}{r}10.14 \\
117.69 \\
0.33 \\
35.64 \\
11.81 \\
33.29 \\
5.52 \\
64.44 \\
25.15 \\
\\
1.19 \\
1.44 \\
0.74 \\
6.63 \\
56.48 \\
7.56 \\
4.17 \\
142.59 \\
5.08 \\
3.07 \\
0.91 \\
2.49 \\
15.24 \\
14.54\end{array}$ & $\begin{array}{r}1.354 \\
12.563 \\
0.022 \\
4.585 \\
2.005 \\
5.022 \\
1.836 \\
8.069 \\
7.898 \\
\\
1.329 \\
1.809 \\
1.084 \\
3.505 \\
2.976 \\
0.995 \\
0.400 \\
4.231 \\
0.623 \\
0.132 \\
0.086 \\
0.333 \\
4.542 \\
1.981\end{array}$ & $\begin{array}{l}0.190 \\
1.764 \\
0.0031 \\
0.642 \\
0.281 \\
0.703 \\
0.262 \\
1165 \\
1.140 \\
0.194 \\
0.261 \\
0.160 \\
0.506 \\
0.417 \\
0.137 \\
0.055 \\
0.581 \\
0.086 \\
0.018 \\
0.012 \\
0.046 \\
0.718 \\
0.275\end{array}$ & $\begin{aligned} 10.21 \\
10.72 \\
6.63 \\
12.87 \\
16.98 \\
15.08 \\
33.24 \\
12.52 \\
31.41 \\
\\
111.59 \\
125.80 \\
146.68 \\
52.91 \\
5.27 \\
13.17 \\
9.590 \\
2.97 \\
12.28 \\
4.31 \\
9.42 \\
13.49 \\
29.81 \\
13.63\end{aligned}$ \\
\hline
\end{tabular}

Table 3

Total mathematical-statistical characteristics of hematological and biochemical indices at the age of 300 days

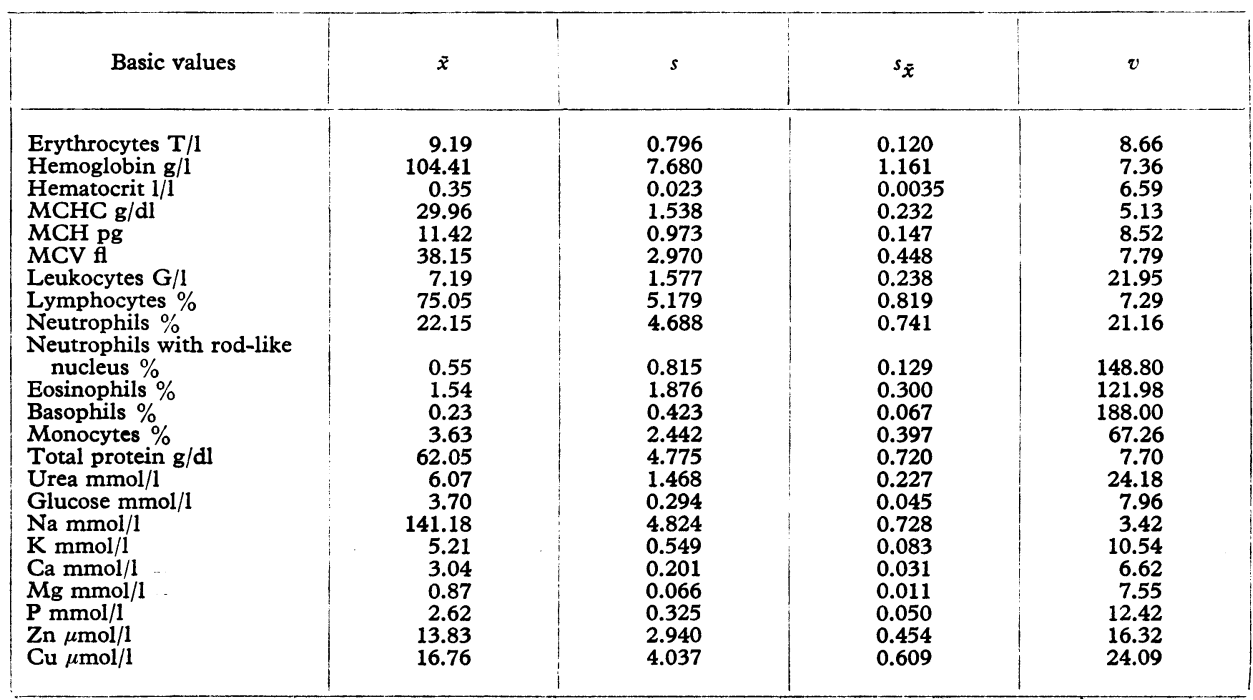


8.6 T/1 (the oldest category of 390-day-old animals) and $10.8 \mathrm{~T} / 1$ in 90 -day-old ram-lambs. Hemoglobin in this age span ranged from $102.7 \mathrm{~g} / 1$ (the last age group) to $117.7 \mathrm{~g} / 1$. The average hematocrit value in ram-lambs during rearing ranged from $0.321 / 1$ to $0.361 / 1$ of blood. The variability within the groups determined by the coefficient of variation showed a low level of variability. Chyla et al. (1975) recorded the same dynamics in these three criteria.

Table 4

Total mathematical-statistical characteristics of hematological and biochemical indices at the age of $\mathbf{3 9 0}$ days

\begin{tabular}{|c|c|c|c|c|}
\hline Basic values & $\bar{x}$ & $s$ & $s_{\tilde{x}}$ & $v$ \\
\hline $\begin{array}{l}\text { Erythrocytes T/l } \\
\text { Hemoglobin g/1 } \\
\text { Hematocrit } 1 / 1 \\
\text { MCHC g/dl } \\
\text { MCH pg } \\
\text { MCV fl } \\
\text { Leukocytes G/1 } \\
\text { Lymphocytes \% } \\
\text { Neutrophils \% } \\
\text { Neutrophils with rod-like } \\
\text { nucleus \% } \\
\text { Eosinophils \% } \\
\text { Basophils \% } \\
\text { Monocytes \% } \\
\text { Total protein g/1 } \\
\text { Urea mmol/1 } \\
\text { Glucose mmol/1 } \\
\text { Na mmol/1 } \\
\text { K mmol/1 } \\
\text { Ca mmol } / 1 \\
\text { Mg mmol/1 } \\
\text { P mmol/1 } \\
\mathrm{Zn} \mu \mathrm{mol} / 1 \\
\mathrm{Cu} \mu \mathrm{mol} / 1\end{array}$ & $\begin{array}{r}8.65 \\
102.73 \\
0.32 \\
31.92 \\
11.93 \\
37.38 \\
5.67 \\
61,15 \\
27.13 \\
13 \\
0.80 \\
6.25 \\
0.41 \\
4.71 \\
57.23 \\
4.39 \\
3.38 \\
137.35 \\
4.34 \\
3.07 \\
0.91 \\
2.59 \\
18.02 \\
17.28\end{array}$ & $\begin{array}{l}0.679 \\
8.200 \\
0.016 \\
2.252 \\
1.188 \\
3.099 \\
1.217 \\
9.546 \\
7.691 \\
\\
1031 \\
4.015 \\
0.867 \\
2.93 \\
4.154 \\
0.824 \\
0.252 \\
3.997 \\
0.297 \\
0.081 \\
0.060 \\
0.412 \\
2.941 \\
2.902\end{array}$ & $\begin{array}{l}0.115 \\
1.392 \\
0.003 \\
0.375 \\
0.201 \\
0.517 \\
0.206 \\
1.837 \\
1.404 \\
\\
0.188 \\
0.759 \\
0.161 \\
0.554 \\
0.666 \\
0.130 \\
0.040 \\
0.632 \\
0.042 \\
0.013 \\
0.009 \\
0.066 \\
0.471 \\
0.465\end{array}$ & $\begin{array}{r}7.85 \\
7.98 \\
4.97 \\
7.06 \\
9.96 \\
8.29 \\
21.47 \\
15.61 \\
28.35 \\
\\
128.88 \\
64.24 \\
209.42 \\
62.16 \\
7.26 \\
18.75 \\
7.46 \\
2.91 \\
6.85 \\
2.64 \\
6.62 \\
15.94 \\
16.32 \\
16.79\end{array}$ \\
\hline
\end{tabular}

Table 5

Significance of differences of the investigated values

\begin{tabular}{|c|c|c|c|c|c|c|}
\hline \multirow{2}{*}{ Parameter } & \multicolumn{6}{|c|}{ Age group } \\
\hline & $1: 2$ & $1: 3$ & $1: 4$ & $2: 3$ & $2: 4$ & $3: 4$ \\
\hline Erythrocytes $T / 1$ & + & $+t$ & $+t$ & $t+$ & ++ & + \\
\hline Hemoglobin $\mathrm{g} / 1$ & - & $+t$ & $t+$ & ++ & $+t$ & - \\
\hline Hematocrit $1 / 1$ & $+t$ & ++ & $+t$ & $+t$ & + & ++ \\
\hline $\mathrm{MCHC} \mathrm{g} / \mathrm{dl}$ & ++ & ++ & - & ++ & $+t$ & ++ \\
\hline $\mathrm{MCH}$ pg & $+t$ & - & ++ & - & - & - \\
\hline MCV fl & - & ++ & $+t$ & ++ & $+t$ & - \\
\hline Leukocytes G/1 & ++ & + & + & $+t$ & - & ++ \\
\hline Lymphocytes \% & - & ++ & ++ & $+t$ & + & $+t$ \\
\hline Neutrophils $\%$ & - & ++ & - & + & - & $+t$ \\
\hline Neutrophils with rod-like nucleus \% & - & + & - & + & - & - \\
\hline Eosinophils \% & - & + & ++ & - & ++ & $+t$ \\
\hline Basophils \% & + & - & - & $+t$ & - & - \\
\hline Monocytes \% & $+t$ & - & - & $+t$ & ++ & - \\
\hline Total protein $\mathrm{g} / 1$ & $+t$ & - & $+t$ & $+t$ & - & ++ \\
\hline Urea $\mathrm{mmol}^{\prime / 1}$ & + & ++ & $t+$ & $+t$ & $t+$ & $t+$ \\
\hline Glucose $\mathrm{mmol} / \mathrm{l}$ & - & $+t$ & $+t$ & $+t$ & $+t$ & $+t$ \\
\hline $\mathrm{Na} \mathrm{mmol} / \mathrm{l}$ & ++ & ++ & - & - & ++ & ++ \\
\hline $\mathrm{K} \mathrm{mmol} / \mathrm{l}$ & + & - & ++ & - & ++ & $+t$ \\
\hline $\mathrm{Ca} \mathrm{mmol/1}$ & + & - & + & - & - & - \\
\hline $\mathrm{Mg} \mathrm{mmol} / 1$ & - & + & - & + & - & - \\
\hline $\mathbf{P} \mathrm{mmol} / \mathrm{l}$ & ++ & ++ & ++ & - & - & - \\
\hline $\mathrm{Zn} \mu \mathrm{mol}$ & $+t$ & ++ & - & - & ++ & ++ \\
\hline $\mathrm{Cu} \mu \mathrm{mol} / 1$ & $+t$ & - & - & $+t$ & $+t$ & - \\
\hline
\end{tabular}

Note: + Significance of differences $P<0.05$

++ Significance of differences $P<0.01$ 
Further indicators of the respiratory function of the erythrocyte (MCHC, $\mathrm{MCH}$ and $\mathrm{MCV}$ ) had a very variable course in the age groups investigated. The range of results characterizing the red blood constituent belong to the ranges of mean values as given e. g. by Thomas and Axford (1968), Sova and Medřický (1972), Hofírek (1978), Jelínek et al. (1982, 1983).

The numbers of leukocytes varied and their average values ranged from 5.52 $\mathrm{G} / 1$ to $7.19 \mathrm{G} / 1$, what is somewhat lower as compared with the total number of white blood cells as described by Redda and Hathout (1957), Sova and Medřický (1972), Jelínek et al. (in print) in ram-lambs of comparable age categories.

The proportion of granulocytes with a segmented nucleus ranged between $22.15 \%$ and $27.13 \%$. The relative number of young forms of neutrophile granulocytes ,rods" ranged from 0.55 to $1.19 \%$. The given range of the differential number of neutrophile granulocytes corresponds with data of Soliman et al. (1965), Ullrey et al. (1965b), Holub et al. (1969). It is, however, lower than has been recorded (Jelínek et al., in print) in breeding rams during rearing in conventional conditions; the mean values ranged from $17.10 \%$ (540 days of age) to $44.57 \%$ (60 days of age). Taken from this aspect, it is possible, in this case, to consider a certain stability of average values which characterizes the total good health condition of the animals investigated. On the other hand, however, the proportion of eosinophile granulocytes had an increasing tendency during rearing with a high variability within the groups. The range of the mean differential number of eosinophile granulocytes - from $0.55 \%$ to $6.25 \%$ - given in the tables corresponds with the data of Redda and Hathout (1957), Sova and Medŕický (1972), Hofírek (1978), Jelínek et al. (in print).

The average values of the most numerous part of the white cell blood constituent, the lymphocytes, ranged between $61.15 \%$ and $75.05 \%$ with a variability of $\mathrm{V}=7.29-15.61 \%$. As far as the other agranulocytic type, the monocyte is concerned, the ranges found in the individual periods of rearing in the blood of the ram-lambs, as well as the proportion of lymphocytes, correspond with the values given by the afore mentioned authors.

The level of total proteins in the blood plasma ranged from 56.48 to $62.10 \mathrm{~g} / \mathrm{l}$. These values correspond with the results of Jagoš et al. (1980) who determined that the range of total proteins in lambs was between 57.3 and $67.9 \mathrm{~g} / 1$. However, these findings are lower as compared with the authors' previous investigations in intensively fattened ram-lambs where the average concentration ranged from 63.0 to $67.03 \mathrm{~g} / 1$ (Jelínek et al. 1983). Further investigations showed that rams with a higher level of total proteins during rearing had a higher clip of wool in the grease which also the value of the coefficient of correlation confirms, $i$. e. $r=0.412^{++}$for wool in the grease and $r=0.439^{++}$for technically clean wool.

No significant correlations were noted between the live weight and/or age and concentration of total protein.

The urea content during rearing showed a decreasing tendency, i. e. the average value of $7.56 \mathrm{mmol} / \mathrm{l}$ at the end of the testing period decreased to $4.40 \mathrm{mmol} / 1$ in the last age category. Between the individual time periods there was a statistically significant to highly significant difference. The increased concentration of urea in the blood plasma signalizes a different level of nitrogen uptake from the feed ration. Whereas in the testing period the complete granulated mixture contained $16.5 \%$ of $\mathrm{N}$ substances, in the following period it was $12.1 \%$. The dynamics of urea content in the blood of sheep can be used for the estimation of the level of nitrogenous nutrition both in cattle and pigs (Vrzgula et al. 1982). 
With the increasing age of the rams, also the glucose content decreased and between these two data (age and glucose concentration) a negative, highly significant relationship was calculated $\left(r=-0.653^{++}\right)$. The decrease of plasma glucose concentration during ontogenesis is connected with the development of the forestomachs and with the increasing role of volatile fatty acids in covering the energy demands of ruminants with these acids (Bartoš 1974). No significant correlation $(r=0.097)$ was found between the level of total proteins and glucose content. The concentrations estimated in the reared rams are in relation with data of Vrzgula et al. (1973, 1982), Hiepe (1975), Hofírek (1978), Jelínek et al (1983).

The dynamics of sodium and potassium concentrations in the blood plasma was relatively low. Nor was any seasonal dependence observed, even though there was a somewhat more expressive decrease of potassium in the period of winter housing. In animals and in man, sodium is very sensitively regulated and its level in the blood plasma changes only a little, especially when salt is provided ad libitum. The present findings are in accordance with those of Vrzgula et al. (1973, 1982), Jagoš et al. (1980a), Jelínek et al. (1983).

The content of calcium was relatively constant $(2.95$ to $3.07 \mathrm{mmol} / \mathrm{l})$, proved also in the lower variability level.

The concentration of magnesium, with average values ranging from 0.87 to $0.93 \mathrm{mmol} / \mathrm{l}$, can be characterized in the same way. The ranges of calcium and magnesium contents were within the limits considered to be referential in sheep. Riede et al. (1974) observed a substantial decrease in the magnesium content in blood plasma of sheep at the beginning of the grazing period; however, they did not observe any symptoms of tetany. Neither did they find any effect of an excessive uptake of nitrogen in the feed ration of sheep on the magnesium level; this is an important difference as compared with cattle, because, in the conditions of Czechoslovakia, the increased content of SNL in the feed ration is the main etiological factor of hypomagnesemia in cattle (Jagoš 1975). Gardner (1973) reported that sheep are more resistant to hypomagnesemic tetany than cattle.

The content of inorganic phosphorus in the blood plasma of reared rams decreased from the initial average value of 2.92 to $2.59 \mathrm{mmol} / 1$ in auction rams. This tendency is in accordance with the data of Jagoš et al. (1980b) who proved a similar dynamics of phosphorus content in calves and young cattle. The increased content of phosphorus influenced the ratio between calcium and phosphorus as well. The content of phosphorus recorded is also due to its increased amount in the feed ration, containing a high proportion of concentrated foods. No effect of the season on the content of calcium and inorganic phosphorus in the blood plasma of rams was proved, in contradistinction to the findings of Bolshedanov (1973) and Lomakina (1974).

The fluctuation of the amount of zinc during rearing was higher but did not exceed the limits of reference values given by Jagoš et al. (1980a) for lambs and sheep.

The average values of the copper content in blood plasma ranged from 14.54 (157 days of age) to $17.45 \mu \mathrm{mol} / 1$ ( 90 days of age) and correspond with findings of Jelínek et al. (1983) intensively fattened ram-lambs of the Merino breed (14.82 to $16.89 \mu \mathrm{mol} / 1)$. The values of plasma copper found by Jagoš et al. (1980a) are somewhat higher $(21.86 \pm 5.68 \mu \mathrm{mol} / \mathrm{l})$. The contents of zinc and copper very well reflect the level of their uptake in the feed ration. In the present investigations it means that the feed ration contained an optimum concentration of zinc 
and copper. It happens very often in practice that the feed rations of fattened lambs have an increased content of copper and could thus cause intoxication by this microelement. Beňuška (1977) drew attention to the problem of copper intoxication and he diagnosed massive chronical intoxication characterized by hemolysis and hepatopathy. Under the conditions of Czechoslovakia, deficiency of copper and zinc is not common, unlike some other countries (Underwood 1971).

\section{Některé biochemické a hematologické parametry krve beranů v průběhu odchovu}

Dynamika vybraných biochemických a hematologických ukazatelů byla sledována na 45 odchovávaných beranech $\mathrm{v}$ centrální odchovně $\mathrm{v}$ chovném období $1982 / 83$.

Výsledky pokusu ukazují, že zjištěné hodnoty odpovídají fyziologickým parametrům. S přibývajícím věkem nastal pokles v počtu erytrocytů, obsahu hemoglobinu, hematokritu, anorganického fosforu a glukózy v krevní plazmě. Úroveň výživy ovlivňovala obsah močoviny a fosforu $\mathrm{v}$ krevní plazmě. Byla prokázána záporná, vysoce průkazná korelace mezi věkem a koncentrací glukózy, dále kladný, vysoce signifikantní vztah mezi obsahem celkového proteinu a množstvím potní $\mathrm{i}$ technicky čisté vlny.

Na základě provedených analýz lze konstatovat, že biochemické nálezy v krevní plazmě lze využít pro posouzení úrovně výživy, a zdravotního stavu beranů v průběhu odchovu. Tyto hodnoty lze považovat za referenční pro plemenné beránky plemene Merino v uvedených věkových kategoriích.

\section{Основная характеристика внутренней среды баранов в процессе доращивания}

У 45 выкармливаемых на центральном откормочном пункте баранов в период 1982-1983 гг. проводились изучения динамики избранных рематологических и биохимических показателей.

Из результатов вытекает, что установленные биохимические и гематологические величины соответствуют физиологическому стандарту. С возрастом было установлено понижение общего количества әритроцитов, содержания гемоглобина, величин гематокрита, неорганического фосфора и глюкозы. На уровень питания оказывало влияние содержание мочевины и фосфора в кровяной плазме. Была установлена отрицательная, весьма существенная коррелция между возрастом и уровнем глюкозы, положительное, значимое отношение между содержанием общих белков и количеством грязной и технически чистой шерсти.

На основе проведенного анализа следуег отмегить, что контроль внутренней среды клиническими и биологическими методами исследования пригоден для оценки уровня питания и состояния здоровья баранов в процессе доращивания. Установленные величины можно считать реферативными для племенных баранов в приведенных возрастных категориях и ими можно пользоваться, исходя из вышеизложенных аспектов. 


\section{References}

BARTOŠ, S.: Metabolismus sacharidů u přežvýkavců. Academia, Praha 1974, 114 p.

BEŇUŠKA, N. M.: Chronická otrava jahniat međou. Sborník referátů z III. semináře ,Zdravotné problémy v súčasných podmienkach chovu oviec“, Prešov, 1977: 294-299.

BOLŠEDANOV, V. S.: Vlijanije solej kobalta, medi i metionina na nekotoryje fiziologičeskije pokazateli i produktivnost ovec. Avtoref. kand. diss., Saratov, 1973, 19 p.

GARDNER, J. A. A.: Control of serum magnesium levels in sheep. Res. vet. Sci., 15, 1973: $149-157$.

HENNIG, A.: Mineralstoffe, Vitamine, Ergotropika. VEB Deutsch. Landwirtschaftsverlag, Berlin, 1972, $558 \mathrm{p}$.

HIEPE, TH.: Schafkrankheiten. VEB Gustav Fischer, Jena, 1975, 412 p.

HOFÍREK, B.: Diagnostika a prevence chorob zvírat. VŠV Brno, 1978, p. 66-71.

HOLUB, A. et al.: Fyziologie hospodářských zvířat. Praha, SZN, 1969, 676 p.

CHYLA, M. - VRZGULA, L. - BARTKO, P. - MICHNA, A.: Hodnoty indexov acidobázickej homeostázy krvi jahniat pri tradičnom spôsobe odchovu. Živ. výr., 20, 1975: 925-931.

JAGOS, P.: K vědeckotechnickému rozvoji ve veterinární medicíně. Veterináŕství, 25, 1975: 4-10.

JAGOŠ, P. et al.: Studium poruch minerálního metabolismu u ovcí. Project report, Brno, University of Vet. Sci., 1980a, 72 p.

JAGOŠ, P. et al.: Vývoj zdravotního stavu telat $\mathrm{v}$ podmínkách velkovýrobních technologií. Pro ject report, Brno, University of Vet. Sci., 1980b, $75 \mathrm{p}$.

JAGOŠ, P. et al.: Vypracování systému preventivní diagnostiky poruch výměny látkové u skotu. Project report, Brno, University of Vet. Sci., 1981, 37 p.

JELÍNEK, P. - HELANOVÁ, I. - PÍCHA, J. - VALACH, Z.: Základní hematologické a biochemické hodnoty u beránkủ ve výkrmu po aplikaci anabolického preparátu Revalor. I. Hematologické hodnoty. Acta univ. agric. (Brno), fac. agron., 30, 1982: 85-93.

JELÍNEK, P. - HELANOVÁ, I. - ZELENKA, J. - FRAIS, Z.: Základní hematologické a biochemické hodnoty u beránků plemena žírné merino $\mathrm{v}$ průběhu intenzívního výkrmu. I. Hematologické hodnoty. Acta univ. agric. (Brno), fac. agron., 31, 1983: 287-292.

JELÍNEK, P. - HELANOVÁ, I. - ILLEK, J. - KONVALINKOVÁ, D.: Základní hematologické a biochemické hodnoty u beránků plemene žírné merino v průběhu intenzívního výkrmu. II. Biochemické hodnoty. Acta univ. agric. (Brno), fac. agron., 31, 1983: 293-297.

JELÍNEK, P. - FRAIS, Z. - HELANOVÁ, I.: Základní hematologické hodnoty u beránků $\mathrm{v}$ průběhu odchovu. Acta univ. agric. (Brno), fac. agron. (in press).

LOMAKINA, A. V.: Profilaktika narušenij belkovo-uglevodnego obmena u tonkorunnych ovec v uslovijach Dagestana. Avtoref. kand. diss., Moskva, 1974, 22 p.

PAYNE, J. M.: The Compton Metabolic profile Test. Production Disease in Farm Animals. Baillière Tindall, London, 1973, p. 236-240.

PAYNE, J. M.: Metabolic Diseases in Farm Animals. William Heinemann Medical Books. Ltd. 1977.

REDDA, H. - HATHOUT, A. F.: The haematological examination of the blood of normal sheep. Brit. Vet. J., 113, 1957: 251-254.

RIED, R. L. - DANIEL, K. - BUTER, J. D.: XII. International Grassland Congress. Moskva, 1974, II., 566 p.

SOLIMAN, K. - ZAKI, K. - SOLIMAN, A.: Effect of sex and age on the blood picture of merino sheep. Fortpfl. Haust., 2, 1965: 118-122.

THOMAS, P. - AXFORD, R. F. E.: Changes in Hemoglobin Concentration and Packed Cell Volume of the Lambs Associated with Age. The Veterinary Record, 83, 1968: 660-661.

SOVA, Z. - MEDŘICKÝ, V.: Základni hodnoty krve u hospodářských zvírat. VII. sdělení. Hemogram u ovcí v ontogenese. Sborník VŠZ, Praha, řada B - Živočišná výroba, 1972, p. $3-25$.

ULLREY, D. E. - MILLER, E. R. - LONG, C. H. - VINCENT, B. H.: Sheep hematology from birth to maturity. II. Leukocyte concentration and differential distribution. J. Anim. Sci., 24, 1965: $141-144$.

VRZGULA, L. - GDOVIN, T. - BARTKO, P. - MIKLUŠČÁK, R.: Niektoré biochemické ukazovatele $v$ krvnom sére a krvný obraz jahniat. Živ. výr., 8, 1965: 631-638.

VRZGULA, L. et al.: Choroby oviec. Bratislava, Príroda 1973. 275 p.

VRZGULA, L. et al.: Poruchy látkového metabolizmu hospodárskych zvierat a ich prevencia. Bratislava, Príroda 1982. 492 s.

VRZGULA, L. - SKALKA, J.: Výkrm jahniat $\mathrm{v}$ industriálnych podmienkach $\mathrm{z}$ aspektu optimalizácie zdravotného stavu. Sborník referátů z III. semináře ,Zdravotné problémy v súčasných podmienkách chovu oviec", Prešov 1977, p. 156-158. 